\title{
The Effect of Dietary Modification and Nutritional Education on Nutrition Care Process (NCP) for Increasing Dietary Intake, Body Weight, and Nutritional Status of Cancer Patients at Risk of Malnutrition and Malnourished in the Inpatient of Dharmais Cancer Hospital
}

\author{
Fauzatun Hadiyati ${ }^{*}$, Ratna Supriastuti, Arifah Mujiharti \\ Nutrition Department, National Cancer Center - Dharmais Cancer Hospital, Jakarta, Indonesia
}

\section{ARTICLE INFO}

Received : 22 September 2020 Reviewed : 15 December 2020 Accepted : 22 March 2021

\section{Keywords:}

body weight, dietary intake, dietary modification, nutrition care process, nutritional education

\begin{abstract}
Methods: The study was a quasi-experiment with one-group pretest-posttest design. The population consisted of all new adult hospitalized cancer patients. The data were collected from July to September 2019. The statistical analysis used paired sample t-test. Dietary modification and nutritional education were given individually based on each nutrition problem of the patient and their nutritional needs.
\end{abstract}

\begin{abstract}
Results: There were 83 patients involved for the study. Most of the patients were female (61.4\%), aged over 45 years (62.7\%), graduated from high school (47\%), were housewives (49.4\%), and had clinical histories of no comorbidities (90.4\%). Most of them had improvement in general condition (74.7\%). The study showed significantly increasing dietary intake of energy (889.7 calorie), protein (36.4 gr), fat (49.3 gr), and carbohydrate (131.4 gr) ( $p=0.000)$. The increasing percentage of nutrient intake to nutritional needs before and after intervention of NCP was 39.8 to $88.6 \%$ for energy, 44.4 to $104 \%$ for protein, 51 to $120 \%$ for fat, and 41.5 to $90.1 \%$ for carbohydrate. The average increase (but not significant related correlation) in body weight was $0.16 \mathrm{~kg}(p=0.141)$ and body mass index $0.05 \mathrm{~kg} / \mathrm{m} 2(p=1.94)$.
\end{abstract}

Conclusions: Dietary modification and nutritional education on NCP improve dietary intakes (energy, protein, fat, and carbohydrate) of cancer patients at risk of malnutrition and being malnourished.

\begin{abstract}
Background: Cancer patients that are hospitalized often have problems with their nutrient intake. Low nutrient intake can be affected by malnutrition. In cancer patients, the intake of nutrients needs to be considered specifically in relation to the occurrence of metabolic changes that lead to decreased nutritional status. The objective of this study is to analyze the effect of dietary modification and nutritional education on nutrition care process (NCP) for increasing dietary intake, body weight, and nutritional status of malnourished cancer patients and cancer patients at risk of malnutrition
\end{abstract}

\author{
*Corresponding author: \\ Fauzatun Hadiyati \\ Nutrition Department, National \\ Cancer Center - Dharmais Cancer \\ Hospital, Jakarta, Indonesia \\ fauzatunhadiyati@gmail.com
}

\section{INTRODUCTION}

According to GLOBOCAN estimation data, there were 18.1 million new cases of cancer and 9.6 million deaths from cancer worldwide in 2018. Breast cancer became the most cases worldwide with an incidence rate of 46.3 per 100,000 population. Meanwhile, the highest death rate was in lung cancer at 18.6 per 100,000 population
[1]. In 2013, the prevalence of cancer on all ages in Indonesia was 1.4 per 1,000 population. However, in 2018, there was an increase to 1.79 per 1,000 population [2].

Patients with cancer tend to be malnourished. Malnutrition can occur before being hospitalized or due to inadequate nutrition. The high prevalence of malnutrition in the hospital between $20-50 \%$ contributes 
to high morbidity and mortality rates, increasing clinical complications, and cost of care, extending the nursing care, increasing readmission, and decreasing the quality of life $[3,4]$. Psychological changes during therapy such as depression and anxiety could affect the dietary intake of cancer patients [5]. Inadequate food intake, anorexia, and cachexia were common problems in cancer patients which affect $50 \%$ of patients with all types of cancer in many stages [6].

In 2004 cohort studies conducted by 3 hospitals (Dr. Sardjito Hospital in Yogyakarta, M. Djamil Hospital in Padang, and Sanglah Hospital in Denpasar), hospitalized patients had insufficient energy intake and a greater risk for malnutrition [7]. Malnutrition is a condition of imbalance between the energy intake of protein and other nutrients with the body's needs, resulting in unwanted effects/functional disorders on tissues, body shape, and function as well as acute and chronic clinical outcomes. This imbalance can be caused by several factors such as insufficient food intake (anorexia, dysphagia, vomiting, etc.) and gastrointestinal disorders such as malabsorption, fistula in the intestine, and metabolic changes to the use of nutrients in the body or a combination of several factors. Malnutrition in cancer patients as a nutritional diagnosis that is enforced by Registered Dietitians in the NCP is inadequate protein and/or energy intake over a long period of time and causes loss of body fat reserves and/or muscle wasting including malnutrition related to chronic diseases characterized by malnutrition. physiological conditions due to chronic disease characterized by $\mathrm{BMI}<18.5$, BMI for the elderly ( $>65$ years) $<22$, weight loss $>20 \%$ in 1 year,> $10 \%$ at 6 months,> $7.5 \%$ at 3 months,> 5\% in 1 month,> 1-2\% in 1 week; loss of subcutaneous fat and muscle mass, energy intake $<50 \%-75 \%$ of the estimated RMR or measured RMR; major infection; medical diagnosis of malnutrition [8]. Malnutrition brings negative impacts to patients and the hospital. The incidence of malnutrition in patients in hospitals have not been solved properly. If the situation continues for a long period, the body will have an adaptation process such as decreased appetite and slowing metabolic. Malnutrition can affect the function and healing of every organ, for example, changes in body weight, decreased heart and kidney function, disorders of the digestive tract system, bacterial infections, and complications of re-feeding syndrome; thus, it is important for hospitals to improve their nutritional status by fulfilling the energy needs as an effort to support the healing process of patients [9].

In cancer patients, the intake of nutrients (energy, protein, fat, and carbohydrates) needs to be considered specifically related to the occurrence of changes in metabolism that have an impact on reducing nutritional status [10]. Nutrient intake requirements for cancer patients are different for each individual. In order to meet the nutrient needs for the optimal healing of patients. Nutrition Care Process (NCP) is needed as a part of nutrition services, and intervention in hospitals was conducted by the Registered Dietitians as health professionals oriented in preventing disease and giving some treatments, especially in food/nutrition. as well as coordinating with the Doctor in charge of patient care and other Health Workers in providing care to patients. A series of Nutrition Care Process includes Nutrition Assessments, Nutrition Diagnosis, Nutrition Interventions, Nutrition Monitoring and Evaluation (ADIME) [11].

The standard operational procedures give quality and safety for patients as regulated in Hospital Accreditation Standards. The Patient Assessment Standard (AP) 1.4 and Service Delivery Standard (PAP) 5 state that the patient screened for nutrition is followed up by nutritional assessment if the patient at risk of nutritional problems receives nutritional therapy and is recorded/documented in the patient's medical record [12]. The objective of this study was to analyze the effect dietary modification and nutritional education on NCP for increasing dietary intake, body weight, and nutritional status of cancer patients at risk of malnutrition and being malnourished.

\section{METHODS}

This study used a quasi-experiment with one-group pretest-posttest design. No control group was used because based hospital accreditation standard, the patient at risk of nutritional problems receives nutritional therapy (Figure 1).

The data collection was conducted from July to September 2019. New adult hospitalized patients at risk of malnutrition based on malnutrition screening tools (MST) score $\geq 2$ were followed up with a nutritional assessment using subjective global assessment (SGA). Based on the results of the SGA, patients with moderate risk of malnutrition (B) and patients with severe risk
Figure 1.

The concept of Quasi eksperimental design with one group pretest-posttest design

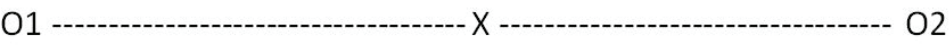

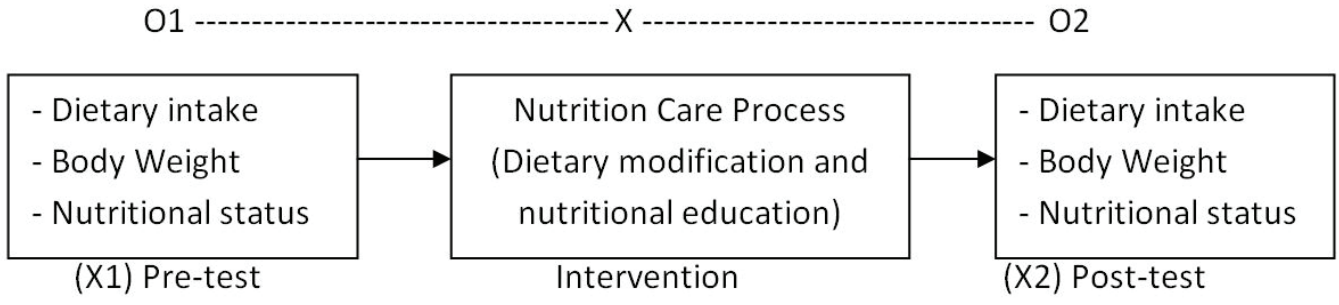


of malnutrition (C) were given NCP. The NCP research step are presented in Supplementary Material Figure S1. After the patient nutritional problems were identified, a nutrition diagnosis was determined to be given further nutrition intervention. Weight loss $>5 \%$ in 1 month or $>$ $7.5 \%$ in 3 months or $>10 \%$ in 6 months, inadequate food and nutrient intake $<75 \%$ of estimated energy requirement for $\geq 1$ month, loss of subcutaneous and muscle mass and fluid accumulation were signs and symptoms of the patient being diagnosed with malnutrition.

In this study, dietary modification is given individually by adding, changing, or replacing the previously given diet related to the composition of food (foodstuff; nutritional value such as high energy high protein diet, low protein diet, low calorie diet, puric acid diet, diabetic mellitus diet; texture consistency such as ordinary food, soft food, blended or liquid food), feeding schedule and composition of enteral nutrition based on the patient's nutritional problems, the patients nutritional needs related to the diseases, and the patient's acceptance of the diet. The nutritional need of every patient is varies. The patient energy need is calculated based on body weight, height, age, gender, activity, and stress factors using Mifflin St-Jeour. The protein need is 1.2$2 \mathrm{~g} / \mathrm{kg} /$ day, fat $20-25 \%$ of total energy, and carbohydrate $55-60 \%$ of total energy. Nutritional education in this study providing nutritional and motivational information for patients and their families which aim to increase knowledge, attitudes, and eating behavior. Nutritional education was given individually with the lecture and discussion method. The time for nutritional education is 3-time meetings with $15-30$ minutes. Dietary intake was traced a month before being hospitalized (nutritional history) obtained by using the semi quantitative food frequency questionnaire (SQ-FFQ), and the day before hospital admission or while being treated at the hospital prescription for initial diet of the doctor in charge of patient care by using 24-hour Food Recall. Observation of dietary intake from hospital food and outside hospital for an average of 3 days was being held regularly for the patient treated in the inpatient room. Monitoring dietary intake from outside the hospital used the 24-hr Food Recall while the dietary intake from the hospital used the Comstock visual estimation method. The body weight measured by using body weight scale. Nutritional status indicators are defined using body mass index (BMI) based on Ministry of Health Republic of Indonesia [13]. The patient body weight was weighed or measured on the first and last day of observation.

Population of the study consisted of all new adult inpatients with cancer. This study sampling method was consecutive sampling. Respondents were filtered by inclusion and exclusion criteria. The inclusion criteria of this study were: patients > 18 years old, new adult hospitalized patients at risk of malnutrition based on MST score $\geq 2$, patients at risk of moderate malnutrition
(B) and severe malnutrition (C) based on SGA, hospitalized patients class I, class II, and class III more than 3 days. patients with chemotherapy, radiation, chemoradiation, immunotherapy, and general condition improvement. Total sample for this study were 83 patients.

The patients not fulfilling the eligibility criteria and excluded were those aged $<18$ years, hospitalized less than 3 days of observation, those who were fasting, those on surgery, those unwilling to provide consent. Statistical analysis with paired sample t-test The data was analyzed with SPSS program version 22. Dietary intake was calculated using Microsoft Excel 2010 based on the 2018 Indonesian Food Composition Table. Determination of energy, protein, fat, and carbohydrate requirements was calculated individually according to the specified diet type. The study had ethical approval by the Committee of Medical Research Ethics of the "Dharmais" Cancer Hospital No.123/KEPK/VII/2019 on July 4, 2019.

\section{RESULTS}

\section{Demography}

There were 83 adult cancer patients involved in this study that had meet the inclusion criteria. Most patients were female (61.4\%), aged over 45 years $(62.7 \%)$, graduated from high school (47\%), were housewives $(49.4 \%)$, and had no clinical history of comorbidities (90.4\%). Most patients $(74.7 \%)$ had improvement in general condition. Most hospitalized patients were at inpatient class III (Table 1).

In this study, there were 40 cancer diagnostics for 83 patients. Most of the patients were diagnosed with breast cancer (19.3\%), 12\% nasopharyngeal cancer, 9.6\% lung cancer, $4.8 \%$ cervical cancer, and $3.6 \%$ acute myeloid leukemia (AML). The nutrition assessment data on NCP are presented in Supplementary Materials Figure S2-S6.

\section{Nutritional diagnoses}

Most of the patients (55.42\%) were diagnosed with malnutrition (NI.5.2/ NC.4.1.2); 39.8\% patients were diagnosed inadequate oral intake (NI.2.1); $2.4 \%$ were diagnosed with the lack of knowledge related to nutrition and food (NB.1.1). Furthermore, there were 1.2\% patients diagnosed by the changes of laboratory values (NC.2.2) related to nutrition acceptability in chewing and swallowing difficulties (NC.1.1) (Figure 2).

\section{Dietary modification}

A total of $53 \%$ of patients were given a texture/ consistency modification (the diet modified into soft, liquid, or blended foods); $25.3 \%$ were given a modification of a high-energy and high-protein diet (the diet modified for energy content/calories and protein according to the acceptability and condition of the patient); $13.3 \%$ were given a modification of a low protein diet (the diet modified according to the patient 
Table 1.

Demographic characteristics

\begin{tabular}{|c|c|c|c|}
\hline Characteristic & Category & $\begin{array}{l}\text { Total } \\
(n=83)\end{array}$ & $\begin{array}{l}\text { Percentage } \\
\text { (\%) }\end{array}$ \\
\hline \multirow[t]{2}{*}{ Gender } & Man & 32 & 38.6 \\
\hline & Woman & 51 & 61.4 \\
\hline \multirow[t]{2}{*}{ Age } & 19-45 old & 31 & 37.3 \\
\hline & $>45$ old & 52 & 62.7 \\
\hline \multirow[t]{5}{*}{ Educational level } & Elementary & 22 & 26.5 \\
\hline & Junior high school & 12 & 14.5 \\
\hline & Senior high school & 39 & 47 \\
\hline & Diploma & 5 & 6 \\
\hline & Bachelor & 5 & 6 \\
\hline \multirow[t]{10}{*}{ Ocupation } & Not work & 5 & 6 \\
\hline & Housewife & 41 & 49.4 \\
\hline & Entrepreneur & 10 & 12 \\
\hline & Government employees & 4 & 4.8 \\
\hline & Farmer & 2 & 2.4 \\
\hline & Midwife & 1 & 1.2 \\
\hline & Retired & 2 & 2.4 \\
\hline & Day laborer & 1 & 1.2 \\
\hline & BUMN employee & 1 & 1.2 \\
\hline & College student & 1 & 1.2 \\
\hline \multirow[t]{5}{*}{ History of comorbidities } & None & 75 & 90.4 \\
\hline & Hypertension (HT) & 4 & 4.8 \\
\hline & Diabetes Mellitus (DM) & 1 & 1.2 \\
\hline & $\mathrm{DM}+\mathrm{HT}$ & 2 & 2.4 \\
\hline & Gastritis & 1 & 1.2 \\
\hline \multirow[t]{3}{*}{ Therapy } & Chemoterapy & 18 & 21.7 \\
\hline & Radiation & 3 & 3.6 \\
\hline & General condition improvement & 62 & 74.7 \\
\hline \multirow[t]{3}{*}{ Inpatient class } & I & 29 & 34.9 \\
\hline & II & 12 & 14.5 \\
\hline & III & 42 & 50.6 \\
\hline
\end{tabular}

Figure 2.

Nutritional diagnoses

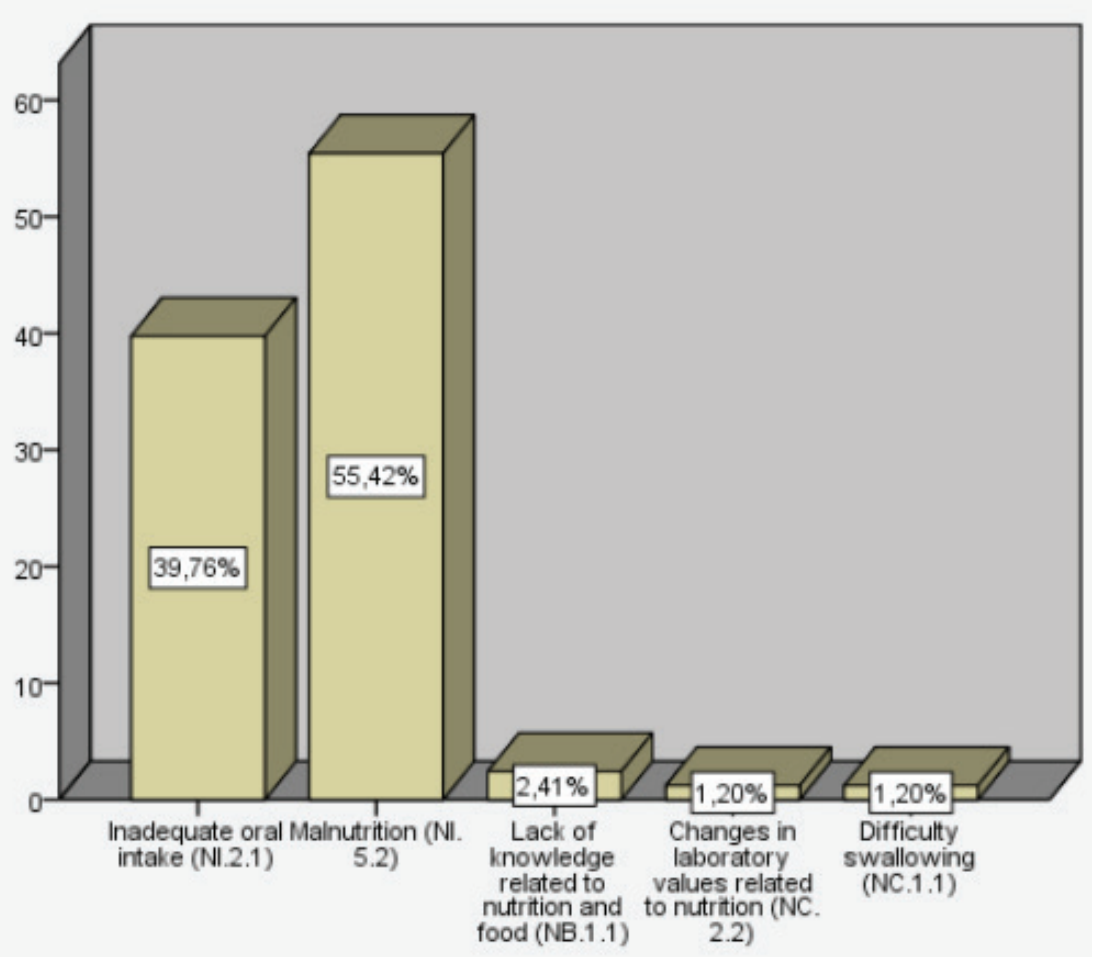




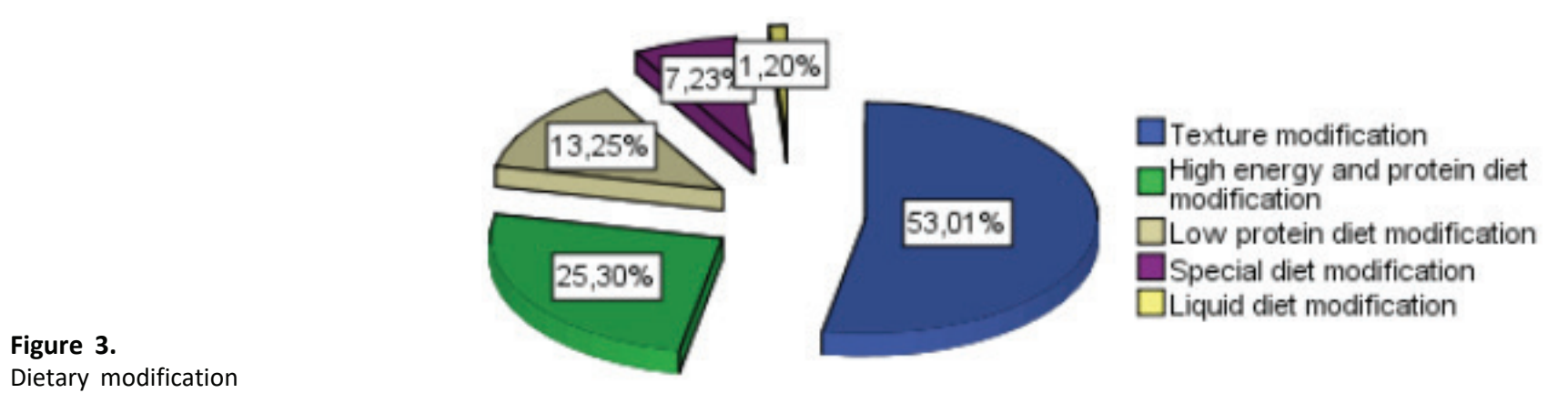

Figure 4.

Percentage

nutritional status

(body mass index)

before and after

NCPs dietary intake

and nutritional

education

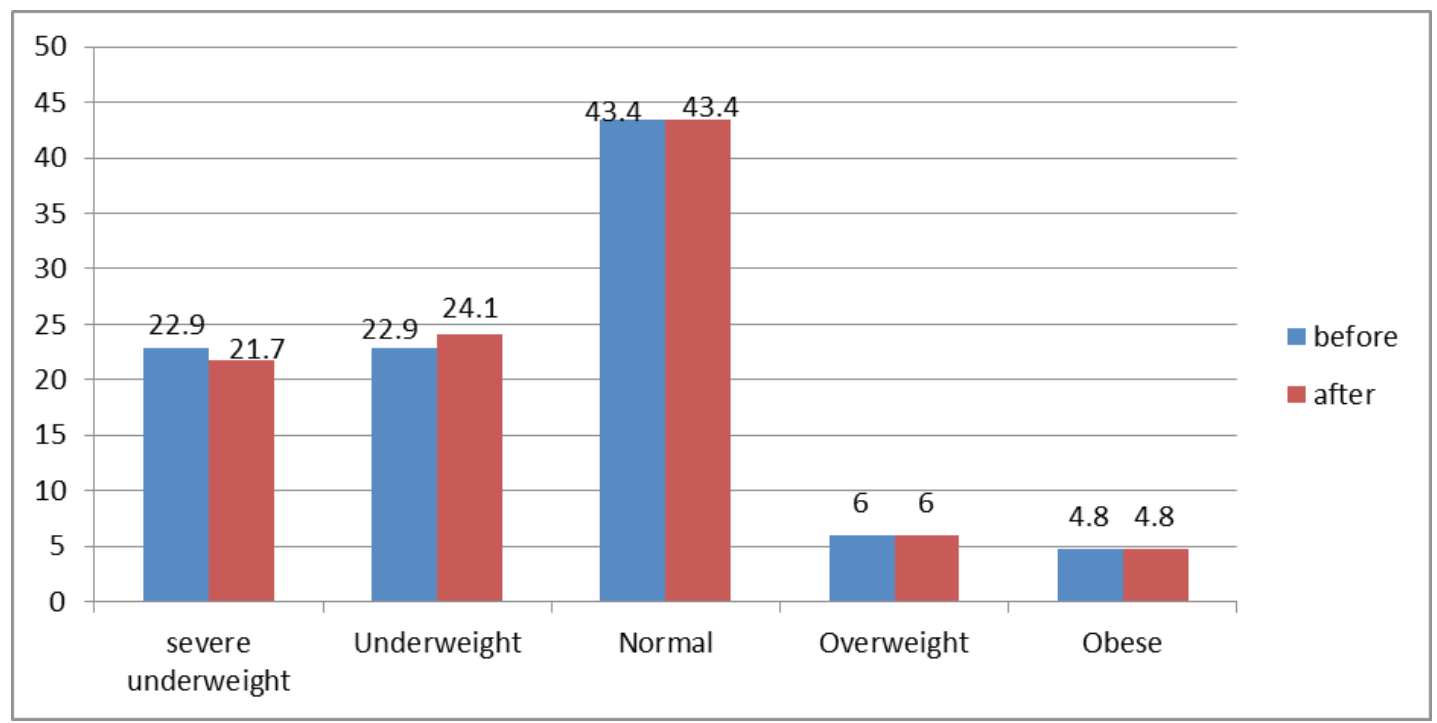

protein requirements based on the results of biochemical/ laboratory tests); $7.2 \%$ were given special dietary modifications related to the results of laboratory examinations and the historical clinical complication diseases such as diabetes mellitus (Figure 3).

\section{The differences dietary intake before and after ncps dietary modification and nutritional education}

The average nutrient intakes of patient eating habits 1 month before being hospitalized were 1346.5 calories of energy, 49.4 grams of protein, 36.9 grams of fat, and 211 grams of carbohydrate. The lowest nutrient intake of the patient was caused by anorexia so that the acceptability of food was very less than the nutritional needs for 1 month before being hospitalized. Meanwhile, the patient's largest nutrient intake was caused by the addition of highcalorie high-protein commercial liquid food consumed by the patient for 1 month before inpatients.

The average nutrient intakes of patient 1 day before hospital admission were 735.1 calories of energy intake, 24 grams protein, 21.1 grams fat, and 115.3 grams carbohydrate. The lowest nutrient intake of patients was caused by patients experiencing severe nausea and vomiting, so they could not consume food or drinks. Meanwhile, the largest nutrient intakes of patients was caused by the patients did not have gastrointestinal complaints (nausea, vomiting, anorexia) and could eat the food normally.

The increase in average dietary intake of patients after dietary modifications and nutritional education on NCP were 889.7 calories, 36.4 grams of protein, 27.9 grams of fat, and 131.4 grams of carbohydrate. Based on paired sample t-test, there were significant differences in energy, protein, fat, and carbohydrate intakes; there was a significant increase in patient energy, protein, fat, and carbohydrate intakes before and after dietary modification and nutritional education on NCP ( $<<0.05$ ) (Table 2).

This study showed that the patients dietary intake to nutritional needs improve before and after intervention of NCPs dietary modification and nutritional education. The average patient dietary intakes were good and met more than $80 \%$ of nutritional needs and less if it was less than $80 \%$ of nutritional needs (Table $\mathbf{3}$ ).

\section{The differences in the nutritional status}

There were differences in the nutritional status for severe underweight status and underweight status before and after NCPs dietary modification and nutritional education with severe underweight and underweight statuses. Meanwhile, the normal nutritional status, overweight and obesity did not have any changes (Figure 4). 
Table 2. The differences dietary intake before and after NCPs dietary modification and nutritional education

\begin{tabular}{|c|c|c|c|c|c|c|c|c|c|c|c|}
\hline \multirow[t]{2}{*}{$\begin{array}{l}\text { Nutrient } \\
\text { intake }\end{array}$} & \multicolumn{3}{|c|}{$\begin{array}{l}\text { Patients historical dietary } \\
\text { intake one month before } \\
\text { hospitalized }\end{array}$} & \multicolumn{3}{|c|}{$\begin{array}{l}\text { Patients dietary intake } \\
\text { one day before hospital } \\
\text { admision }\end{array}$} & \multicolumn{3}{|c|}{$\begin{array}{l}\text { Patients dietary intake after } \\
\text { ncps dietary modification and } \\
\text { nutritional education }\end{array}$} & \multirow{2}{*}{$\begin{array}{l}\text { Differences } \\
(\Delta) \\
\text { (Average } \pm S D)\end{array}$} & \multirow[t]{2}{*}{$\mathbf{p}$} \\
\hline & Min & Max & Average $\pm S D$ & Min & Max & Average $\pm S D$ & Min & Max & Average $\pm S D$ & & \\
\hline $\begin{array}{l}\text { Energy } \\
\text { (calorie) }\end{array}$ & 337 & 2885.9 & $1346.5 \pm 520.6$ & 0 & 2309.5 & $735.1 \pm 502.1$ & 571.9 & 3154.5 & $1632.1( \pm 510.4)$ & $\begin{array}{l}889.7 \\
\pm 539.8\end{array}$ & 0.000 \\
\hline $\begin{array}{l}\text { Protein } \\
\text { (gram) }\end{array}$ & 9.5 & 154 & $49.4 \pm 25.2$ & 0 & 72.3 & $24 \pm 17.7$ & 12.6 & 106.9 & $56.4( \pm 19.2)$ & $\begin{array}{l}36.4 \\
\pm 45.4\end{array}$ & 0.000 \\
\hline Fat (gram) & 8.7 & 111 & $36.9 \pm 18.8$ & 0 & 77 & $21.1 \pm 18$ & 14.2 & 107 & $49.3( \pm 19.1)$ & $\begin{array}{l}27.9 \\
\pm 20.3\end{array}$ & 0.000 \\
\hline $\begin{array}{l}\text { Carbohydrate } \\
\text { (gram) }\end{array}$ & 33.9 & 476.4 & $211 \pm 84$ & 0 & 492.2 & $115.3 \pm 86.1$ & 75.5 & 491.9 & $247.7( \pm 79.7)$ & $\begin{array}{l}131.4 \\
\pm 96.9\end{array}$ & 0.000 \\
\hline
\end{tabular}

\section{Table 3.}

The average percentages of dietary intake for patients' nutritional needs before and after NCP

\begin{tabular}{lll}
\hline \multirow{2}{*}{ Nutrient intake } & \multicolumn{2}{l}{$\begin{array}{l}\text { The average percentages of nutrient } \\
\text { intake based }\end{array}$} \\
\cline { 2 - 3 } & Before & After \\
\hline Energy (calorie) & $39.8 \%$ & $88.6 \%$ \\
Protein (gram) & $44.4 \%$ & $104 \%$ \\
Fat (gram) & $51 \%$ & $120 \%$ \\
Carbohydrate (gram) & $41.5 \%$ & $90.1 \%$ \\
\hline
\end{tabular}

Table 4.

The differences in body weight and nutritional status based on patients body mass index before and after NCP

\begin{tabular}{lllll}
\hline Antropometry & $\begin{array}{l}\text { Average } \pm \text { SD } \\
\text { Before }\end{array}$ & $\begin{array}{l}\text { After } \pm \text { SD } \\
\text { After }\end{array}$ & $\begin{array}{l}\text { Mean } \\
\text { Difference }\end{array}$ & $\mathbf{p}$ \\
\hline Weight $(\mathrm{kg})$ & $48.7 \pm 11.5$ & $48.8 \pm 11.4$ & 0.16 & 0.141 \\
BMI $(\mathrm{kg} / \mathrm{m} 2)$ & $19.3 \pm 4.8$ & $19.4 \pm 4.2$ & 0.05 & 0.194 \\
\hline
\end{tabular}

The average initial patient body weight in the hospital was 48.7 ( \pm 11.5 ) kg. Meanwhile, based on measurements at the last day of observation, the average body weight value was 48.8 ( \pm 11.4$) \mathrm{kg}$. The average value in general for 3 days of observation was an increase in body weight of $0.16 \mathrm{~kg}$; however, based on paired sample t-test, there were no significant differences in patient's weight before and after NCPs dietary modification and nutritional education $(p=0.141)$. The average Body Mass Index (BMI) of the initial patient in hospital was $19.3( \pm 4.3) \mathrm{kg} / \mathrm{m} 2$, but on the last day of observation, the average value of BMI was 19.4 ( \pm $4.2) \mathrm{kg} / \mathrm{m} 2$. The average value in general for 3 days of observation was an increase in BMI of $0.05 \mathrm{~kg} / \mathrm{m} 2$, but based on paired sample t-test, there was no significant difference in the patient BMI from the initial hospital admission until the completion of the observation $(p=$ 0.194). This study showed that there was no significant difference in nutritional status based on patient BMI before and after NCPs dietary modification and nutritional education (Table 4).

\section{DISCUSSION}

The studies about the effect of dietary modification and nutritional education on NCP of cancer patients at risk of malnutrition and malnourished were still rare in Indonesia. Statistically, this study showed that there was a significant difference or an increase in dietary intake of cancer patients who were at risk of malnutrition and patients who were malnourished before and after getting NCPs dietary modification and nutritional education. This study in line with the research of Handayani et al. [13] showed that there was a difference or an increase in the initial and final feeding intake of patients with metabolic syndrome at Sidoarjo Regional General Hospital after being given the management of a standardized nutrition care process or NCP. Research by Susetyowati [14] showed that an increase in food intake was energy and protein after a standardized nutritional care process was given where at the beginning of the hospital patient intake of food was very low. The results of this study were also in line with the research by Yunita [15] showing that there was a significant increase in energy, protein, 
fat, and carbohydrate intakes of type- 2 diabetes mellitus patients after being given the management of a standardized nutrition care process or the NCP. Research by Suhaema et al. [16] showed that the application of NCP has an effect on improving the nutritional intake of type-2 diabetes mellitus patients at the NTB Provincial General Hospital.

Another study showed that after receiving a Standardized NCP, the intake of energy and protein inpatients at Dr. Hasan Sadikin General Hospital Bandung had increased significantly and it was positively related [17]. Research by Purwaningsih et al. [18] showed that dietary modification in cancer patients has an effect on decreasing anorexia and increasing food intake in cancer patients with chemoradiation therapy in the inpatient room of RSUP Dr. Kariadi and there was a significantly increase in body weight and nutritional status (BMI). This study not in line with Purwaningsih's research. In this study, there was an increase of the average body weight and BMI, but not significant. Length of observation day can probably affect the significant increase of body weight and BMI. Purwaningsih's research was 21 days observation different with this study for 3 days observation. Research by Balgis et al. [19] showed that the administration of commercial dietary modifications can increase the energy and protein intake of patients with chronic prehemodialysis kidney disease in RSUP DR. M. Djamil Padang. Proper diet management will provide positive support for the therapeutic response given during treatment [20]. Patient eating intake is a matter of great concern for cancer patients. As in breast cancer patients undergoing radiotherapy, the lower the intake of food is, the more severe the condition of malnutrition will be wherein the intake of food also affects nutritional status and quality of life [21].

Another study showed that the provision of nutritional interventions through food modification can increase the intake of patients who are at risk of malnutrition as well as those who have been malnourished [22].

Research into nutritional care interventions for inpatients at hospitals in Denmark shows that there is an increase in the percentage of energy and protein intake before and after the intervention, from $72 \%$ to $85 \%$ for protein and $85 \%$ to $103 \%$ for energy [23]. This finding was also reported by Miller et al. [24] that by providing NCP with nutritional interventions in the form of providing primary food and snacks to patients in veterans-specific hospitals in the United States, targets are set in nutrition intervention strategies (feeding and nutritional education) can be achieved and increased with anthropometry.

Research by Murphy and Howarter [25] showed that the implementation of NCP by providing nutrition education increases knowledge and motivation to increase patient food intake. Provision of nutritional education can improve nutrition knowledge, attitudes, and levels of energy and protein adequacy of hospital food [26]. Providing nutritional education can also increase the patient's regular food intake as seen from hospital food scraps which decrease after the patient is given nutrition education [27]. One of the efforts to improve the knowledge and abilities of individuals or families about nutrition is done with nutrition education. Education provided and communication processes that are well-established will provide knowledge, attitudes, and trust. Knowledge influences one's lifestyle in consuming food that influences nutrition intake. Knowledge of good nutrition will make a person better in calculating the amount and type of food consumed. Poor nutritional knowledge will affect eating arrangements. The imbalance intake of nutrients has a significant effect on an increased risk of disease and its complications and a great impact on decreasing nutritional status to impatient. The standardized of nutritional need of food intake was one of the indicators to the success of nutrition intervention [15].

In general, cancer patients tend to lose weight, so the BMI also decreases. This is due to a decrease in fat tissue and skeletal muscle mass. Cancer patients have many specific changes in protein, fat, and carbohydrate metabolism. Metabolic changes often occur in cancer patients in hypermetabolic condition. However, in this study, in averages, there was an increase in body weight and BMI after the interventions of NCPs dietary modification and nutritional education for 3 days of observation; nevertheless, the results of the paired t-test showed no significant difference between body weight and nutritional status based on BMI before and after respondents were given NCPs dietary modification and nutritional education ( $p>0.05)$. The results of this study were in line with Fayakun's research that showed there was a difference change or increase in body weight and nutritional status based on the BMI of respondents when they went home, but it was not significantly related to the length of stay in hospital ( $p>0.05$ ) [17]. This study is also in line with Weta and Wirasamadi [28] research that showed there was a change or difference in body weight and nutritional status based on BMI from the beginning of admission to hospital discharge with an average length of treatment of 6.4 days, but from the length of treatment (1- 3 days), there was no significant change in body weight and BMI. The results of this study were also in line with the research by Ernawati et al. [29] showing that giving a high protein milk diet could improve nutritional status of adult patients with pulmonary TB through increasing the body weight, energy, and protein intake. Changes in body weight within a short treatment time due to dietary management can occur but not in significant increases of 0.2-0.3 kg [30]. The increase of nutritional status index (body weight and $\mathrm{BMI}$ ) during 
the 3 days of observation in the hospital in this study was in line with the fulfillness of the nutritional needs of the respondents. In line with Susetyowati et al. [21], it showed that there was a significant relation between food intake and nutritional status. Based on the results of this study, dietary modification and nutritional education on NCP played an important role in helping cancer patients at risk of malnutrition and malnourished for overcoming their nutritional problems related to malnutrition to improve their intake and fulfill their nutritional needs.

This study has several limitations. Patients with chemotherapy did not have a long day of hospitalization. Meanwhile, patients with radiation and general condition improvement were treated for a long time of hospitalization. For that, we specified 3 days of observation as intervention time for the patients to analyze the effectiveness of dietary modification and nutritional education on NCP. The intervention of dietary modification varied because it was treated individually based on nutritional needs of the patients and the acceptability of the patient to receive their diets. Furthermore, we suggest further study about NCP with specific dietary modification and nutritional education for malnourished patients with specific cancer therapy.

\section{CONCLUSIONS}

Dietary modification and nutritional education on Nutrition Care Process (NCP) improves dietary intake (energy, protein, fat, and carbohydrate) of cancer patients at risk of malnutrition and malnourished in the inpatient of National Cancer Center (NCC)-Dharmais Cancer Hospital. On the other hand, research about the effect of specific nutritional intervention for specific types of cancer prone to malnutrition is recommended.

\section{DECLARATIONS}

\section{Competing of Interest}

The authors declare no competing interest in this research.

\section{Ethics Approval}

This research had ethical approval by the Committee of the Medical Research Ethics of the "Dharmais" Cancer Hospital No.123/KEPK/VII/2019 on July 4, 2019.

\section{Acknowledgment}

The authors would like to thank the Research and Development of the National Cancer Center (NCC)Dharmais Cancer Hospital for giving the opportunity and support in this research. Finally, we would like to acknowledge all dietitians and staffs of Nutrition Department National Cancer Center (NCC)-Dharmais Cancer Hospital in giving lots of contribution for this study.

\section{REFERENCES}

1. Ferlay J, Colombet M, Soerjomataram I. Estimating the global cancer incidence and mortality in 2018: GLOBOCAN sources and methods. Int J Cancer. 2019;144:1941-53.

2. Badan Penelitian dan Pengembangan Kesehatan. Hasil Utama RISKESDAS. Kementrian Kesehatan RI. 2018 [cited 29 Agustus 2020]. Available from: https:// www.litbang.kemkes.go.id/hasil-utamariskesdas-2018/

3. Tappenden KA, Quatrara B, Parkhurst ML, et al. Critical role of nutrition in improving quality of care: an interdisciplinary call to action to address adult hospital malnutrition. J Acad Nutr Diet. 2013;113:1219-37.

4. Sherry CL, Sauer AC, Thrush KE. Assessment of the nutrition care process in US Hospitals using a webbased tool demonstrates the need for quality improvement in malnurition diagnosis and discharge care. Curr Dev Nutr. 2017;1:e001297.

5. RCN. Nutrition in children and young people with cancer [Internet]. 2020 [cited 29 April 2020]. Available from: http://www.RCN_Nutrition_2020_Final.pdf

6. Flood KL, Brown CJ, Carroll MB, Locher JL. Nutritional process of care for older adults admitted to an oncology acute care for elders unit. Critical Reviews in Oncology/ Hematology. 2011;78:73-8.

7. Kusumayanti IGA, Hadi H, Susetyowati. Faktor-faktor yang mempengaruhi kejadian malnutrisi pasien dewasa di ruang rawat inap rumah sakit. Jurnal Gizi Klinik Indonesia. 2004; 1(1):9-17.

8. Kementerian Kesehatan Republik Indonesia. Pedoman Proses Asuhan Gizi Terstandar (PAGT). Jakarta: Direktorat Jendral Bina Gizi dan Kesehatan Ibu dan Anak Kementerian Kesehatan RI;2014.49

9. Wijayanti A. Penatalaksanaan diet kanker. In: Hardinsyah, Supariasa IDN, editors. Ilmu gizi teori dan aplikasi. Jakarta: EGC; 2016.351-58

10. Kurniasari FN, Harti LB, Ariestiningsih AD, dkk. Buku ajar gizi dan kanker. Jakarta:UB Press;2017.7

11. Kementerian Kesehatan Republik Indonesia. Pedoman Pelayanan Gizi Rumah Sakit (PGRS). Jakarta: Direktorat Jendral Bina Gizi dan Kesehatan Ibu dan Anak Kementerian Kesehatan RI;2013.16-22

12. Komisi Akreditasi Rumah Sakit (KARS). Standar nasional akreditasi rumah sakit edisi 1. Jakarta: Komisi Akreditasi Rumah Sakit (KARS) ;2017.158

13. Handayani D, Astutik P, Nurwati Y, Mahar MA. Efektivitas penatalaksanaan proses asuhan gizi terstandar terhadap perbaikan asupan pasien sindrom metabolik di RSUD Sidoarjo. Journal Gizi Universitas Muhamadiyah Semarang. 2018;7(1):31-9.

14. Susetyowati, Hamam $H$, Asdie AH, Hakimi $M$. Penerapan algoritma asuhan gizi terstandar berbasis skrining gizi. Jurnal Gizi Klinik Indonesia. 2014;11(1):20-30. 
15. Yunita Y, Asdie AH, Susetyowati. Pelaksanaan proses asuhan gizi terstandar (PAGT) terhadap asupan gizi dan kadar glukosa darah pasien diabetes melitus tipe 2. Jurnal Gizi Klinik Indonesia. 2013;10(2):82-91.

16. Suhaema, Iswidhani, Sulasty SU. Penerapan nutrition care process (NCP) pada pasien diabetes melitus tipe 2 di rumah sakit umum Provinsi NTB berpengaruh pada perbaikan asupan zat gizi dan kadar glukosa darah. Jurnal Kesehatan Prima. 2013;7 (1):1087-99.

17. Fayakun YL and Susetyowati. Peranan proses asuhan gizi terstandar terhadap asupan gizi, status gizi dan lama rawat pada pasien rawat inap di RSUP Dr Hasan Sadikin Bandung Tahun 2010 [Tesis] [internet]. Yogyakarta: Universitas Gadjah Mada;2011 [cited 29 July 2019]. Available from : http://lib.ugm.ac.id/ ind/?page_id=248

18. Purwaningsih S, Darmono SS, Judiono. Pengaruh pemberian diet modifikasi terhadap status gizi pasien kanker dengan kemoradiasi. Medica Hospitalia. 2014;2(3):205-11.

19. Balgis P, Probosuseno, Astuti H. Pemberian diet modifikasi komersil dan pengaruhnya terhadap asupan makanan dan status gizi pasien penyakit ginjal kronik pre hemodialisis di RSUP DR. M. Djamil Padang. Jurnal Gizi Klinik Indonesia. 2008;5(2): 71-7.

20. Raymond JL, Morrow K. Krause and Mahan's Food \& The Nutrition Care Process 15th edition. Canada:2021;231.

21. Susetyowati, Pangastuti R, Dwidanarti SR, Wulandari $\mathrm{H}$. Asupan makan, status gizi dan kualitas hidup pasien kanker payudara di RSUP Dr Sardjito Yogyakarta. Jurnal Gizi Klinik Indonesia. 2018;14(4):146-53.

22. Baldwin C, Kimber KL, Gibbs M, Weekes CE. Supportive interventions for enhancing dietary intake in malnourished or nutritionally at risk adults (review). Cochrane Database Syst Rev. 2016;12(12):CD009840.
23. Lassen KO, Kruse F, Bjerrum M, et al. Nutritional care of Danish Medical Inpatients: effect on dietary intake and the occupational groups perspectives on intervention. Nutr J. 2004;3:1-3.

24. Miller PE, Miller N, Faith J, Lewis AE. Implementation and evaluation of outcomes related to the nutrition care process through the use of electronic health records. Journal of The American Dietetic Association. 2010;110(9):A-86 Suppl 2-Abstracts.

25. Murphy, Howarter. Patient Outcome from Nutrition Education and councelling Reports (Nutrition Care Process Terminology via ANDHI). Journal of The American Dietetic Association. 2017;117(9).Supl.

26. Simanjuntak RR, Martha IK, Ali R. Pengaruh pesan gizi singkat dan pendidikan gizi terhadap praktik makan pasien rawat inap di rumah sakit umum daerah Salatiga. Jurnal Gizi Indonesia. 2016; 4(2):120-24.

27. Herawati MR, Dyah NS, Cahyo H. Pengaruh edukasi gizi terhadap sisa makan pasien dengan diet makanan biasa. Jurnal Riset Gizi 2014;2(1):66-71.

28. Weta IW, Wirasamadi NLP. Kecukupan zat gizi dan perubahan status gizi pasien selama dirawat di rumah sakit umum pusat Sanglah Denpasar. Gizi Indon. 2009;32(2):139-49.

29. Ernawati K, Nazza RR, Ayu LAP, et al. Perbedaan status gizi penderita tuberkulosis paru antara sebelum pengobatan dan saat pengobatan fase lanjutan di Johar Baru, Jakarta Pusat. Majalah Kedokteran Bandung. 2018;50(2):74-8.

30. Par'i HM. Penilaian status gizi dilengkapi Proses Asuhan Gizi Terstandar. Jakarta: EGC;2016.201 